\title{
Bi-layer Electrolyte for Preventing Solid Oxide Fuel Cell Stack Degradation
}

\author{
Mi Young Park, Hongyeul Bae*, and Hyung-Tae Lim ${ }^{\dagger}$ \\ School of Materials Science and Engineering, Changwon National University, Gyeongnam 641-773, Korea \\ *Fuel Cell Project, Research Institute of Industrial Science and Technology (RIST), Pohang 790-600, Korea \\ (Received June 18, 2014; Revised July 3, 2014; Accepted July 7, 2014)
}

\section{고체산화물 연료전지 스택 열화 방지를 위한 전해질 기술 \\ 박미영 · 배홍열* · 임형태 ${ }^{\dagger}$ \\ 창원대학교 신소재공학부 \\ *포항산업과학연구원 연료전지연구단 \\ (2014년 6월 18일 접수 ; 2014년 7월 3일 수정 ; 2014년 7월 7일 채택)}

\begin{abstract}
The stability of a solid oxide fuel cell (SOFC) stack is strongly dependent on the magnitude and profile of the internal chemical potential of the solid electrolyte. If the internal partial pressure is too high, the electrolyte can be delaminated from the electrodes. The formation of high internal pressure is attributed to a negative cell voltage, and this phenomenon can occur in a bad cell (with higher resistance) in a stack. This fact implies that the internal chemical potential plays an important role in determining the lifetime of a stack. In the present work, we fabricate planar type anode-supported cells $\left(25 \mathrm{~cm}^{2}\right)$ with a bi-layer electrolyte (with locally increased electronic conduction at the anode side) to prevent high internal pressure, and we test the fabricated cells under a negative voltage condition. The results indicate that the addition of electronic conduction in the electrolyte can effectively depress internal pressure and improve the cell stability.
\end{abstract}

Key words : Planar type SOFC, Cell imbalance, Stack degradation

\section{1. 서 론}

연료전지의 기전력은 단위 셀 하나 당 최대 $1 \mathrm{~V}$ 정도 로 원하는 출력을 얻기 위해서는 직렬로 여러 장의 셀을 스택하는 단계가 필요하다. 스택을 구성하는데 있어서 가 장 중요한 점은 직렬로 연결된 셀 간의 성능 편차를 최 소화하는 것이다. 이의 중요성은 다음의 예로 설명될 수 있 다. 서로 다른 용량을 가진 전지를 혼용하는 경우 전체 배터리 팩의 효율은 감소된다. 상대적으로 낮은 용량을 가진 전지는 전체 배터리 팩에서 높은 저항을 가지므로 저항으로 작용되어 이와 같은 현상이 발생되는 것이다. 문제는 이뿐만이 아니다. 상대적으로 낮은 전압, 용량을 가지는 전지는 과충전/과방전이 발생할 수 있으며, 전지 내부에 급격히 증가하는 가스에 의해 파열 및 누액을 유 발할 수 있다. ${ }^{1-8)}$

즉, 연료전지 스택 내에서 하나의 셀이 큰 성능 편차를

${ }^{\dagger}$ Corresponding author: Hyung-Tae Lim

E-mail : htaelim@changwon.ac.kr

Tel : +82-55-213-3716 Fax : +82-55-262-6486
보인다면 Fig. 1과 같이 낮은 성능을 가진 셀이 같은 전 류밀도에서 역(-) 전압에서 작동되며 급격한 열화로 물리 적 파괴가 일어나 스택 전체의 작동이 멈추게 될 것이다. ${ }^{8)}$ 이와 같은 현상은 실제로 직렬로 연결된 전기화학 장치 에서 보편적으로 발생하는 현상으로 전지의 안정성과 상 용화를 위해서는 셀 간 성능 편차를 최소화함은 물론, 스 택에서의 cell imbalance 현상을 근본적으로 이해하고 해 결하는 것이 중요하다. 다시 말해, 연료전지 스택 운전을 계속 진행하기 위해서는 역전압에서도 열화 없이 작동 할 수 있는 기술이 필요하다. 본 논문에서는 역전압에 의한 열화현상을 근본적으로 해결할 수 있는 전해질 기술에 대 하여 설명하고자 한다.

현재 고체산화물 연료전지의 전해질로 가장 널리 사용 되는 물질은 $8 \mathrm{~mol} \% \mathrm{yttria}$ 가 도핑된 지르코니아 (YSZ)이 다. YSZ는 yttria의 첨가로 인해 발생된 산소빈자리에 의 해 산소 이온 전도성이 지배적인 물질로 전자 전도성을 거의 보이지 않으며 산화/환원 분위기에 관계없이 화학적 으로 안정하다는 장점을 가진다. ${ }^{9}$ 여기서 산소 이온 전도 성이라는 점은 관점의 차이에 따라 다른 양상을 보이게 된다. 성능 관점에서 순수한 산소 이온 전도성은 높은 개 


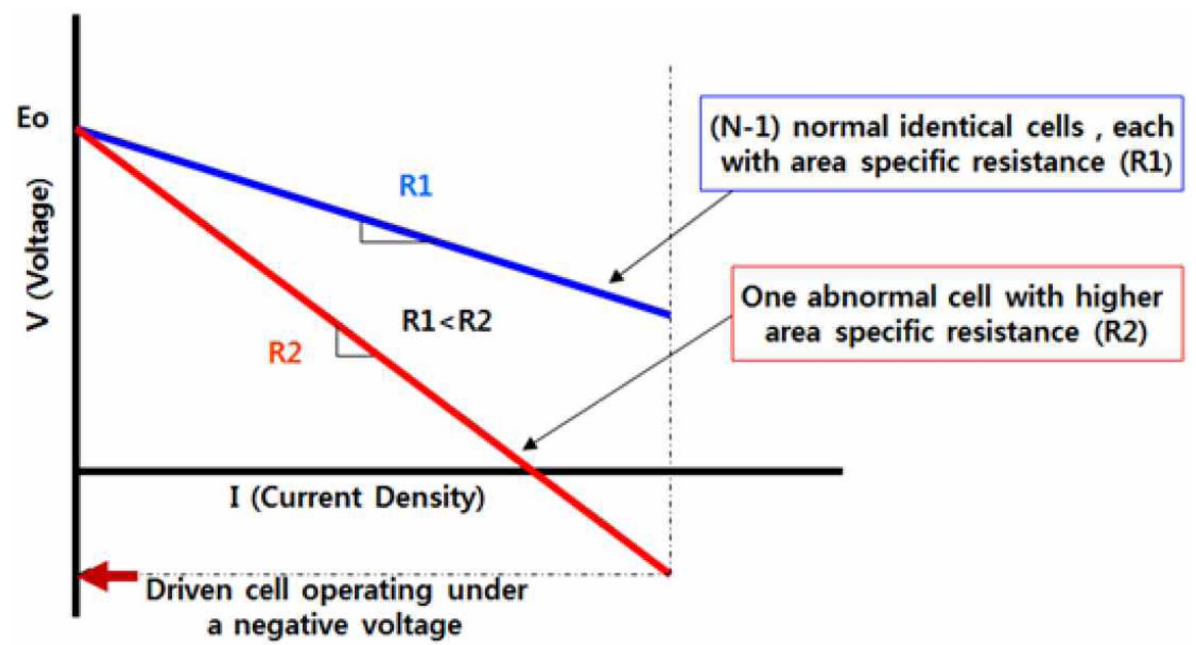

Fig. 1. Cell voltage vs. current density plots for a stack with one bad cell operated under a negative voltage.

방회로 전압과 이에 따른 높은 출력이 장점으로 작용된 다. 그러나 내구성 관점에서 순수한 산소 이온 전도성은 더 이상 장점으로 작용하지 않는다. 위에 언급한 역(-)전 압에서의 작동은 고체 전해질 내부에 비정상적으로 높은 산소화학 포텐셜을 형성, 전극과 전해질 계면의 박리를 일으킬 수 있다는 것이다. 이를 산소 이온과 전자의 방향으 로 설명하기 위해서는 local equilibrium의 가정이 필요하다 7-9)

$$
\frac{1}{2} O_{2}+2 e^{\prime} \rightarrow O^{2-}
$$

Local equilibrium은 전해질을 이동하는 산소 이온 하나 는 $1 / 2$ 개의 산소 분자와 2 개의 전자가 평형을 이루고 있 다고 가정하는 것으로 전해질 내부를 이동하는 산소 이 온은 식 (1)과 같이 산소와 전자로 나타낼 수 있다. 거시 적인 관점에서 전해질 내부를 이동하는 것은 산소 이온 이지만 국부적 관점에서 즉, local equilibrium 가정 하에 서 전해질 내부를 이동하는 것은 산소 분자와 전자로 나 누어 생각 할 수 있다. 아래의 식 (2)는 관계식 (1)을 전 기화학 및 화학 포텐셜로 표현한 것이다.

$$
\frac{1}{2} \mu_{O_{2}}+2 \tilde{\mu}_{e}=\tilde{\mu}_{O^{2-}}
$$

식 (2)에서 $\tilde{\mu}_{O^{2}}$ 는 산소의 화학 포텐셜을 나타낸 것이고 $\tilde{\mu}_{e}, \tilde{\mu}_{O^{2-}}$ 는 각각 전자와 산소 이온의 전기화학 포텐셜을 나타낸 것이다.

식 (3), (4)는 산소 이온과 전자의 전류밀도를 전기 전 도도와 전기화학 포텐셜의 구배로 나타낸 것으로 이것을 다시 식 (2)의 local equilibrium 가정을 이용하여 변환하면 $\varphi=-\frac{\tilde{\mu}_{e}}{e}$ 에 의해 ASR (Area Specific Resistance)가 포함된 식 (5), (6)으로 나타낼 수 있다.

$$
\begin{aligned}
I_{O^{2-}} & =\frac{\sigma_{O^{2-}}}{2 e} \nabla \tilde{\mu}_{O^{2-}}=\frac{\sigma_{O^{2-}}}{2 e} \nabla\left(\frac{1}{2} \mu_{O_{2}}+2 \tilde{\mu}_{e}\right)=\sigma_{O^{2-}} \nabla\left(\frac{1}{4 e} \mu_{O_{2}}-\varphi\right) \\
I_{e} & =\frac{\sigma_{e}}{e} \nabla \tilde{\mu}_{e}=-\sigma_{e} \nabla \varphi \\
I_{O^{2-}} & =\frac{1}{4 e} \frac{\Delta \mu_{O_{2}}}{r_{O^{2-}}}-\frac{\Delta \varphi}{r_{O^{2-}}} \\
I_{e} & =\frac{\Delta \varphi}{r_{e}}
\end{aligned}
$$

위 두 식에서 산소이온의 변화량과 $\varphi$ 의 변화량을 전극 과 전해질의 계면 간의 차이로 변환하면 아래의 (7), (8) 로 정리된다.

$$
\begin{aligned}
& \mu_{O_{2}}^{c}=\mu_{O_{2}}^{I}+4 e\left(r_{O^{2}}^{c} I_{O^{2-}}-r_{e}^{c} I_{e}\right) \\
& \mu_{O_{2}}^{a}=\mu_{O_{2}}^{I I}+4 e\left(r_{O^{2-}}^{a} I_{O^{2-}}-r_{e}^{c} I_{e}\right)
\end{aligned}
$$

여기서 $\mu_{O_{2}}^{I}, \mu_{O_{2}}^{I I}$ 는 각각 다공성 양극, 음극의 $\mu_{O_{2}}$ 이며, $\mu_{O_{2}}^{c}, \mu_{O_{2}}^{a}$ 는 각각 양극과 전해질 경계에서 전해질 내부 (양극 바로 아래 전해질 내부)의 $\mu_{O_{2}}$ 와 음극과 전해질 경 계에서 전해질 내부(음극 바로 아래 전해질 내부)의 $\mu_{O_{2}}$ 이 다. $r_{O^{2-}}^{c}$ 와 $r_{e}^{c}$ 는 각각 양극/전해질 경계에서 이온과 전자 에 대한 $\mathrm{ASR}$ 을, $r_{O^{2}}^{a}$ 와 $r_{e}^{c}$ 는 음극/전해질 경계에서 이온 과 전자에 대한 $\mathrm{ASR}$ 을 나타낸다.

정상적인 작동환경에서 즉, 양 $(+)$ 전압에서 전해질을 통 과하는 산소 이온의 이동은 양극에서 음극으로 발생하므 로 이온 전류밀도의 부호는 $I_{i}<0$ 이다. 또한 양극은 음극 보다 높은 전기 포텐셜 $\varphi$ 를 가지므로 전해질을 이동하는 전자의 이동은 음극에서 양극방향으로 발생하므로 전자 전류밀도의 부호는 $I_{e}>0$ 이다. 이를 식 (7), (8)에 넣어 정 리하면 다음과 같은 관계식이 성립된다. 


$$
\mu_{O_{2}}^{I} \geq \mu_{O_{2}}^{c} \geq \mu_{O_{2}}^{a} \geq \mu_{O_{2}}^{I I}
$$

이는 전해질 내부의 산소 화학 포텐셜 값은 두 전극(다 공성)의 산소화학 포텐셜 범위 안의 값을 가진다는 것으 로 이해할 수 있다.

반면에 음의 전압에서 셀이 작동되는 경우, 전해질을 이 동하는 산소 이온의 이동은 양의 전압 경우와 마찬가지로 양극에서 음극으로 발생, 이온 전류밀도의 부호는 $I_{i}<0$ 이다. 전자의 이동방향은 역전압으로 인해 음극에 높은 전기 포텐셜 $\varphi$ 이 형성되므로 전자 전류밀도의 부호는 $I_{e}<0$ 이다. 즉 전자의 전류방향과 이온의 전류방향이 같 아지게 된다. 이를 식 (7), (8)에 넣어 정리하면 다음과 같 은 관계식이 성립된다.

$$
\mu_{O_{2}}^{I}>=<\mu_{O_{2}}^{c}, \quad \mu_{O_{2}}^{a}>=<\mu_{O_{2}}^{I I}
$$

$I_{i}$ 와 $I_{e}$ 가 동일한 방향으로 이동되면서 전해질 내부의 화 학 포텐셜은 두 전극의 산소화학 포텐셜 범위에서 벗어 날 수 있다. 즉, 전해질 내부에 비정상적으로 크거나 작 은 $\mu_{O_{2}}$ 의 형성이 가능하다는 뜻으로 내부의 산소화학 포 텐셜은 예측 불허하다.

실제 YSZ 전해질을 적용한 셀로 구성된 스택레벨에서 발생하는 역(-)전압에 의한 열화를 모사하는 실험을 진행 한바 있다. ${ }^{8)}$ 실험은 역(-)전압에 해당하는 전류밀도를 단 전지에 걸어주는 방식으로 YSZ 전해질의 단전지 셀은 시 간 당 셀 전압의 감소를 보였으며 역(-)전압 작동 후, 개 방회로전압 뿐 아니라 출력밀도의 감소도 관찰되었다. 또 한 주사현미경을 통한 사후분석에서도 음극과 전해질 계 면에서의 박리가 관찰되었다. 따라서 역(-)전압 작동 시 전해질 내부에 발생하는 높은 산소분압은 박리(열화)를 일으키는 것으로 해석할 수 있다.

그러나 전자 전도성을 보이는 dopant가 첨가된 $\mathrm{YSZ}$ 의 경우 전자 전도성의 생성으로 역(-)전압 시 발생하는 음극 /전해질 계면의 높은 산소분압이 낮아져 박리(열화)를 보 이지 않았다. ${ }^{9)}$ 이는 아래의 식 (11), (12)에 의해서 설명 된다.

$$
\begin{aligned}
& \frac{1}{2} \Delta \mu_{O_{2}}=\Delta \tilde{\mu}_{O^{2-}}+2 e \Delta \varphi \\
& \frac{1}{2}\left(\mu_{O_{2}}^{a}-\mu_{O_{2}}^{I I}\right)=\left(\tilde{\mu}_{O^{2-}}^{a}-\tilde{\mu}_{O^{2-}}^{I I}\right)+2 e\left(\varphi^{a}-\varphi^{I I}\right)
\end{aligned}
$$

식 (11)은 앞의 식 (2)에서 $\varphi=-\frac{\tilde{\mu}_{e}}{e}$ 와 전해질 내 포텐 셜의 변화량으로 나타낸 것으로 이를 다시 풀어쓰면 식 (12)와 같이 나타낼 수 있다. 역(-)전압 시, 음극과 전해 질의 $\varphi$ 의 변화량 $\left(\varphi^{a}-\varphi^{I I}\right)$ 은 전자전도에 의해 작아지게 되 며, 이에 의해 산소화학 포텐셜의 변화량(산소분압)이 낮 아지는 것을 볼 수 있다. ${ }^{9)}$ 즉, 전해질 내부의 전자전도는
역(-)전압 시 전극과 전해질 계면에 발생하는 비정상적인 산소화학 포텐셜을 완화, 물리적 열화(박리)를 방지 할 수 있다는 것이다. 그러나 전자 전도성이 증가된 전해질은 연료전지의 개방회로 전압 등 기본 성능의 감소로 이어 질 수 있는 단점을 지니고 있다. 즉, 성능 관점에서 는 순수한 이온 전도성을 가지는 YSZ가 적합하며, cell imbalance로 인한 스택열화 관점에서는 약간의 전자 전도성 을 가지는 dopant가 첨가된 YSZ가 적합하다고 할 수 있다.

따라서 본 연구에서는 높은 안정성과 성능을 모두 구 현할 수 있도록 양극/전해질 계면에는 순수한 이온 전도 성의 YSZ를 배치하고 역(-)전압 작동에서 높은 산소분압 의 형성으로 박리가 일어날 수 있는 음극/전해질 계면에 는 전자 전도성을 가지는 dopant가 첨가된 YSZ를 배치하 여 이중층 구조의 전해질을 고안하였다. 이러한 새로운 구조의 전해질을 실제 스택에 적용할 수 있도록 $25 \mathrm{~cm}^{2}$ $(5 \mathrm{~cm} \times 5 \mathrm{~cm})$ 크기의 평판형 음극 지지체 셀을 제조하여 역(-)전압 시 열화율/내구성 테스트를 실시하였다.

\section{2. 실험 방법}

본 연구에 사용된 고체산화물 연료전지는 Fig. 2에서 보 여지는 것처럼 6개의 층을 포함하는 음극 지지체이다. 음 극 지지체 (AS : Anode Support, Ni+YSZ)와 음극 기능 층 (AFL : Anode Functional Layer, Ni+YSZ)은 생산성과 비용을 고려하여 tape casting 공법을 통해 제작되었으 며 ${ }^{10)} 1050^{\circ} \mathrm{C}$ 에서 2 시간의 가소결 후, drop coating 방법 으로 전해질 층을 제조하였다. 이중층 구조의 전해질 제 조는 먼저 $8 \mathrm{~mol} \%$ ceria doped $\mathrm{YSZ}(8 \mathrm{CYSZ})$ 물질의 전 해질 코팅 후 $950^{\circ} \mathrm{C}$ 에서 1 시간의 열처리 과정을 거쳐 $\mathrm{YSZ}$ 층 코팅이 이루어졌다. ${ }^{10)}$ 이후 $1400 \sim 1450^{\circ} \mathrm{C}$ 에서 4 시간 동안 소결되었다. 전해질의 총 두께는 약 $~ 15 \mu \mathrm{m}$ 로 이는 YSZ 단층 적용과 대비해 추가적인 ohmic loss를 방지하기 위해 YSZ 단층과의 두께 차이를 최소화하였다. 양극 기능층 (CFL : Cathode Functional Layer, LSM+YSZ)

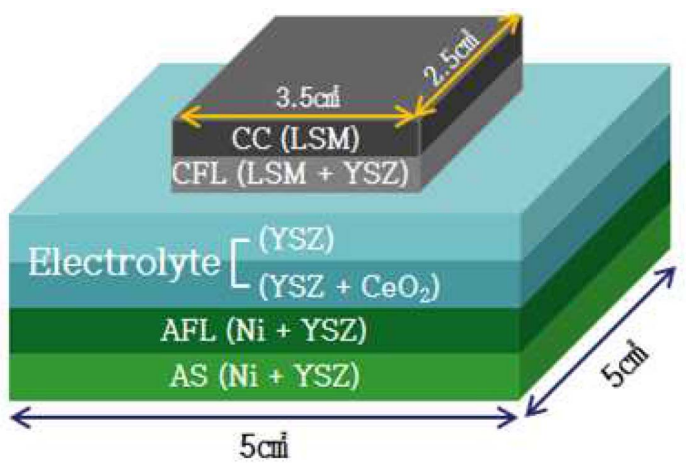

Fig. 2. A schematic of an anode supported cell including a bilayer electrolyte. 


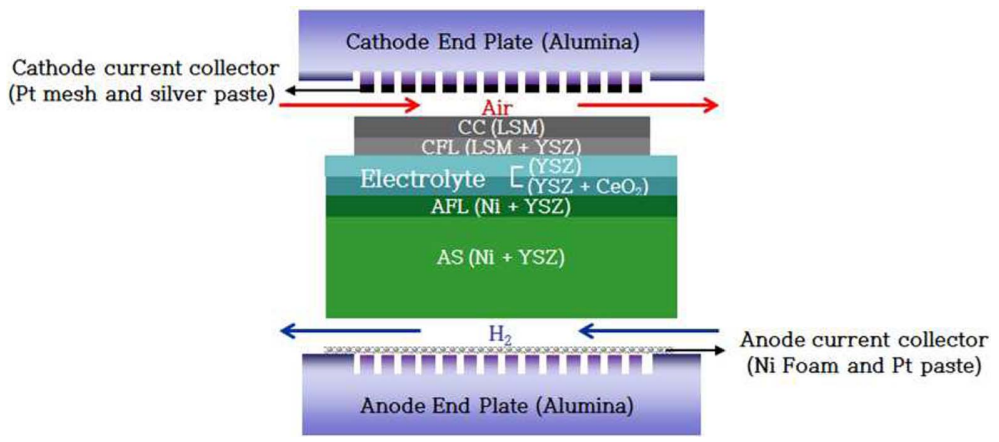

Fig. 3. A schematic of the unit cell configuration.

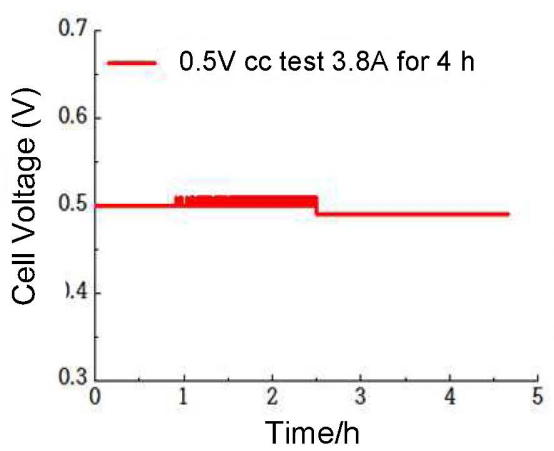

(a)

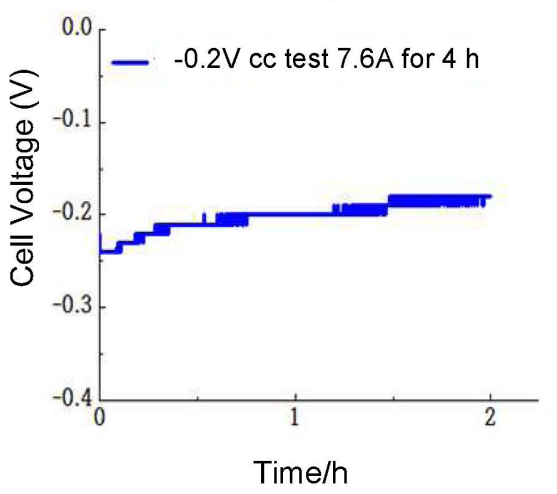

(c)

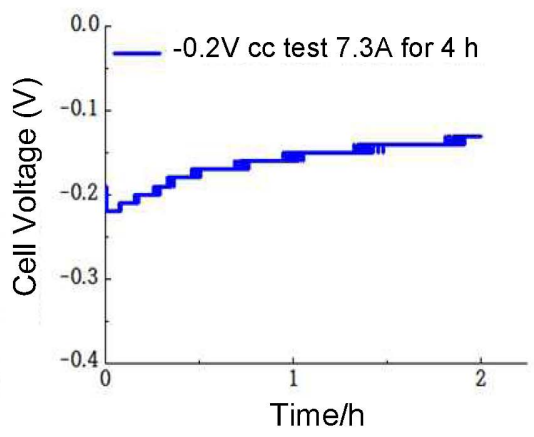

(b)

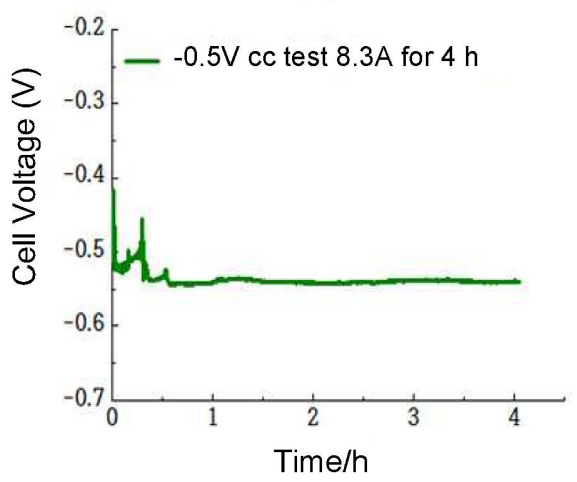

(d)

Fig. 4. Plot of the cell voltage vs. time: (a) at $\sim 3.8 \mathrm{~A}(0.5 \mathrm{~V})$ for $4 \mathrm{~h}$, (b) at $\sim 7.3 \mathrm{~A}(-0.2 \mathrm{~V})$ for $2 \mathrm{~h}$, (c) at $\sim 7.6 \mathrm{~A}(-0.2 \mathrm{~V})$ for $2 \mathrm{~h}$, and (d) at $\sim 8.3 \mathrm{~A}(-0.5 \mathrm{~V})$ for $4 \mathrm{~h}$.

과 양극 집전층 $(\mathrm{CC}$ : Current Collector $\mathrm{LSM})$ 은 소결된 전해질의 표면에 screen print되었으며 각각 $1170^{\circ} \mathrm{C}$, $1160^{\circ} \mathrm{C}$ 에서 열처리하였다. 셀 면적은 $25 \mathrm{~cm}^{2}(5 \mathrm{~cm} \times 5 \mathrm{~cm})$ 이며 양극 면적은 $8.75 \mathrm{~cm}^{2}(2.5 \mathrm{~cm} \times 3.5 \mathrm{~cm})$ 이다.

셀은 Fig. 3와 같이 특별히 제작된 ceramic end plate에 장착되었다. 모든 테스트는 작동 온도인 $800^{\circ} \mathrm{C}$ 에서 행해 졌으며, 전자부하기(PLZ164WA, KIKUSUI)에 의해 정전 류 및 출력 테스트를 측정하였다. 테스트는 이전의 논문 과 동일한 순서로 진행되었다. ${ }^{11)}$ 혼합가스에 의해 환원된 셀은 음극과 양극 각각 수소, 공기 분위기에서 개방회로 전압, 출력밀도 등 기본적인 성능 평가를 실시하였다. 이
후 양 $(+)$ 전압, $\sim 0.5 \mathrm{~V}$ 에 해당하는 전압에서 약 5 시간 동 안 정전류 테스트를 진행하였고, power supply (GPR 0830 $\mathrm{HD}, \mathrm{GW} \mathrm{INSTEK})$ 를 이용하여 역(-)전압, $-0.2 \mathrm{~V}$ 와 $0.5 \mathrm{~V}$ 정도에 해당하는 전압에서 각각 4 시간 동안 정전 류 테스트를 끝으로 실험은 종료되었다. 테스트 후 셀의 전극과 전해질 간의 박리를 관찰하기 위하여 주사현미경 을 통해 파단면을 관찰하였다.

\section{3. 결과 및 고찰}

국부적으로 전자 전도성이 증가한 전해질이 적용된 평 
판형 셀은 $1 \mathrm{~V}$ 이상의 개방회로 전압을 보였다. Fig. 4(a) 는 정전류 테스트 동안 시간에 따른 전압의 변화를 나타 내는 그래프로 약 5시간 동안 $3.8 \mathrm{~A}(\sim 0.5 \mathrm{~V})$ 에서 작동되 었으며 전압강하를 보이지 않았다. 정전류 테스트 후, 인 가된 부하를 제거하고 개방회로 전압상태로 돌린 후 출 력 특성 평가를 진행하였다. 그 후, 약 4시간 동안 약 $7.3 \mathrm{~A} \sim 7.6 \mathrm{~A}(-0.2 \mathrm{~V})$ 조건에서 역(-)전압 테스트를 진행하 였다 (Fig. 4(b), (c)). $-0.2 \mathrm{~V}$ 에서의 정전류 테스트는 2시 간 단위로 끊어 시행되었다. 이는 전압의 상승으로 인해 $-0.2 \mathrm{~V}$ 의 전압이 아닌 이보다 작은 전압에서 테스트가 이 루어지므로 처음에 계획했던 실험과는 다른 결과를 얻을 수 있기 때문이다. 처음 2시간 동안은 Fig. 4(b)와 같이 $-0.21 \mathrm{~V}$ 에서 $-0.13 \mathrm{~V}$ 로 전압이 상승했으며, 이 후 2 시간 은 Fig. 4(c)와 같이 약 $7.6 \mathrm{~A}$ 에서 진행, $-0.22 \mathrm{~V}$ 에서 $0.18 \mathrm{~V}$ 의 전압의 변화를 보였다. 이는 비정상 (역전압) 작 동 중에도 성능의 감소가 없음(약간의 성능 향상)을 나타 내는 것이라 할 수 있다. 4 시간의 정전류 테스트 후 인 가된 부하를 제거, 개방회로 상태로 전환 후 이전과 동일 하게 출력 특성 평가를 진행하였다. 그 후, 약 $8.3 \mathrm{~A}(-0.5 \mathrm{~V})$ 에서 4 시간 동안 정전류 테스트를 진행하였고, Fig. 4(d)와 같이 $-0.508 \mathrm{~V}$ 에서 $-0.54 \mathrm{~V}$ 로 전압이 상승되는 결과를 얻 었다. 이 후 동일하게 출력 특성 평가가 진행되었다.

Fig. 5은 환원 직후, 양 $(+)$ 전압, 역(-)전압 정전류 테스 트 후의 출력밀도를 비교하는 그래프이다. $-0.2 \mathrm{~V}$ (4시간), $-0.5 \mathrm{~V}$ (4시간)의 장시간 역전압 테스트에서도 출력밀도 의 감소는 관찰되지 않았으며 특히 $-0.2 \mathrm{~V}$ 작동 후에는 오히려 약간의 성능 증가가 있었다. 이는 양극의 current treatment 효과에 의한 것으로 사료된다. 모든 실험이 종 료된 후 셀을 실온까지 냉각하여 주사현미경을 통한 사 후분석을 실시하였으며 Fig. 6과 같이 역(-)전압 테스트 후 셀의 전극과 전해질 간의 박리는 관찰되지 않았다. 이 러한 실험 결과를 통하여 역(-)전압, 비정상적인 작동에 서도 이중층 구조의 전해질이 적용된 평판형 셀에서는 전 해질 내부의 산소분압의 증가로 인한 열화(박리)현상이 발생하지 않음을 다시 한 번 확인 할 수 있었다.

전해질 내부 산소분압이 감소되었음은 reference electrode 를 전해질 내부에 삽입하여 측정한 정량적인 산소분압 값 으로 설명될 수 있으며 이는 이전 논문에 상세히 기록되 어있다. ${ }^{11)}$ 개방회로 조건에서는 (11)에 따라 산소 이온의 전기화학 포텐셜의 변화는 0 으로 수렴하므로 $\nabla \varphi=$ $\frac{1}{4 e} \nabla \mu_{O_{2}}$ 과 같이 $\Delta \varphi$ 의 변화량은 $\mu_{O_{2}}$ 의 변화량과 같다는 식을 얻을 수 있다. 따라서 전해질 내부에서 이루어지는 산 소의 화학 포텐셜 변화값은 다음과 같이 계산된다(식 (13)).

$$
\Delta \varphi=\left(\varphi^{\text {Ref }}-\varphi^{\text {Anode }}\right)=\frac{\left(\mu_{O_{2}}^{\text {Ref }}-\mu_{\mathrm{O}_{2}}^{\text {Anode }}\right)}{4 e}=\frac{k T}{4 e} \ln \left(\frac{P_{O_{2}}^{\text {Ref }}}{P_{O_{2}}^{\text {Anode }}}\right)
$$

식 (13)에서 $\Delta \varphi=\left(\varphi^{R e f}-\varphi^{A n o d e}\right)$ 는 전해질 내부의 어느
한 지점으로부터 음극까지의 전압변화를 나타내는 것으 로 reference electrode를 이용하여 실험적으로 측정 가능 하다. 순수한 YSZ 전해질 $(30 \mu \mathrm{m})$ 의 산소분압을 측정한 결 과 음극에서 약 $10 \mu \mathrm{m}$ 떨어진 전해질의 산소분압은 약 $1.00 \times 10^{-5} \mathrm{~atm}$ 으로 측정되었다. 그러나 $8 \mathrm{CYSZ}$ 전해질 $(30 \mu \mathrm{m})$ 에서 음극으로부터 약 $10 \mu \mathrm{m}$ 떨어진 전해질의 산 소분압은 약 $8.19 \times 10^{-17} \mathrm{~atm}$ 으로 ceria가 첨가되지 않은 $\mathrm{YSZ}$ 에 비해 $\sim 10^{12}$ 정도 낮은 분압을 보이는 것으로 확 인되었다. ${ }^{9,11)}$ 이와 같은 차이는 $8 \mathrm{CYSZ}$ 의 ceria의 환원에 의해 생성된 전자 전도성에 의한 것이다.

따라서 본 연구를 통하여 전자 전도성이 국부적으로 증 가한 이중층 구조의 전해질 기술은 셀의 기본 성능은 그 대로 유지하면서 동시에 열화로 인한 박리를 방지하는데 효과적이며 또한 button 사이즈 뿐 아니라 대면적 평판형 셀에도 유효함을 확인 할 수 있었다.

\section{4. 결 론}

스택 내의 cell imbalance 현상은 스택 전체의 성능 감 소와 작동 중지를 발생시키는 심각한 문제로 셀 간의 성 능편차 최소화와 셀의 내구성 증대가 요구된다. Cell imbalance로 인한 열화는 전해질 내부의 산소 분압 거동 과 밀접한 관련이 있으며, 셀 자체의 내구성 증대를 위한 전해질 내부의 국부적인 전자 전도성의 증가는 음극과 전 해질 계면에 발생하는 높은 산소화학 포텐셜을 효과적으 로 감소시킬 수 있다. 더불어 전자 전도성에 의한 개방회 로 전압의 감소와 성능의 감소를 가져오지 않았으므로 이 중층 구조의 전해질은 성능의 감소는 가져오지 않으면서

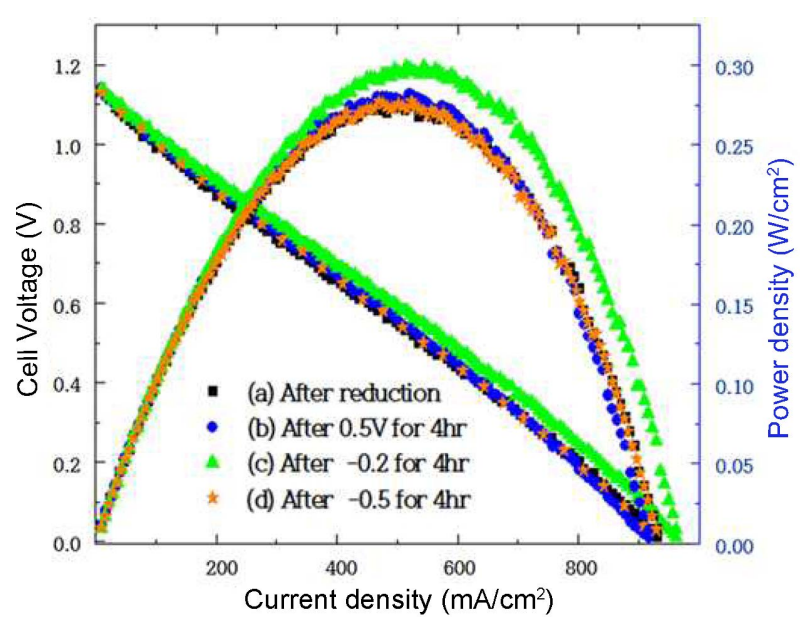

Fig. 5. Voltage vs. current density and power density plot of the planar type cell corresponding to : (a) initial test, (b) after operated under $\sim 0.5 \mathrm{~V}$ for $4 \mathrm{~h}$, (c) after operated under $\sim-0.2 \mathrm{~V}$ for $4 \mathrm{~h}$, and (d) after operated under $\sim-0.5 \mathrm{~V}$ for $4 \mathrm{~h}$. 

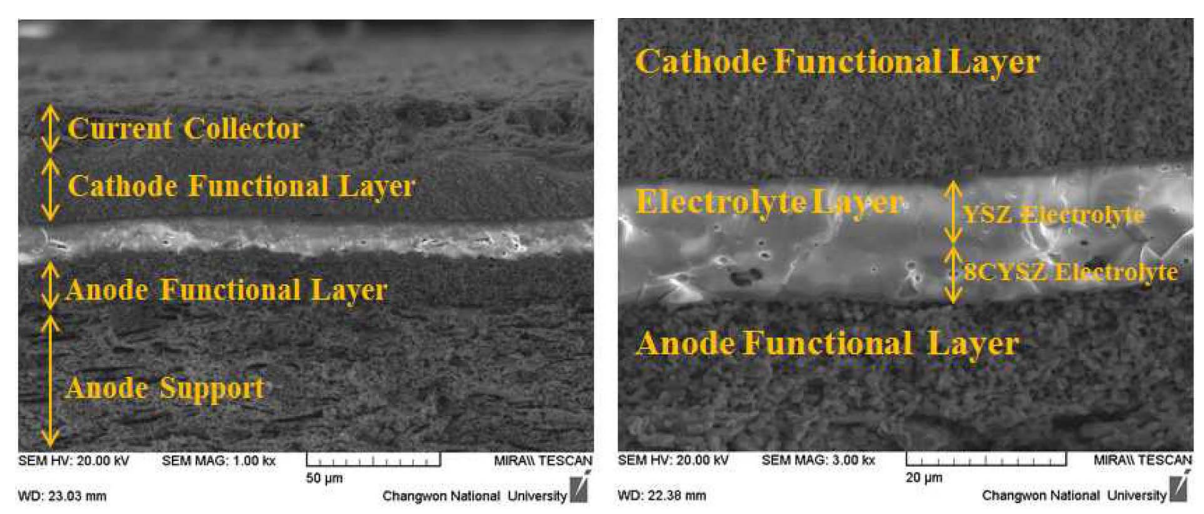

Fig. 6. SEM micrograph of the cross section of the planar type cell after the operation under a negative voltage, showing that anode is well bounded to the electrolyte.

셀의 내구성을 증가시키는데 효과적인 구조라 할 수 있 다. 이전의 연구는 button 셀 단위에서 cell imbalance에 의한 역(-)전압 작동을 모사하였으며 본 연구에서는 실제 스택에 적용 가능한 평판형 셀에서의 역(-)전압 테스트를 실시하여 이중층 구조의 전해질이 상용화 단계에 적합한 지 여부를 판단하였다. 셀의 제조에서는 대량생산이 용이 하며 비교적 비용이 적게 드는 tape casting 공법을 통해 제조되었으며 전해질은 drop coating으로 이중층의 전해 질을 제조하였다. 실험 결과, 역(-)전압의 작동에서 열화 에 의한 성능 감소와 박리를 보이지 않았으며 이는 전해 질내의 국부적인 전자 전도성은 스택 내에서 불량 셀로 인한 역(-)전압 발생 시에도 셀의 안정성을 유지할 수 있 는 즉, 스택 운전을 중지 없이 계속 할 수 있는 유효한 기술임을 의미한다. 또한 이와 같은 기술은 고체산화물 연료전지 뿐 만 아니라 직렬로 연결, 사용하는 모든 전기 화학 셀에 적용 가능하므로 이차전지의 전해질 내 전자 전도성을 적절히 부여하면 cell imbalance로 인한 배터리 팩의 열화 및 안전사고를 방지 할 수 있을 것이다.

\section{Acknowledgment}

이 논문은 포스코 4차 Genesis 연구과제와 2012년도 정 부(교육과학기술부)의 재원으로 한국연구재단의 기초연구 사업 지원을 받아 수행된 것임 (2012R1A1A1013782).

\section{REFERENCES}

1. J. B. Olson and E. D. Sexton, "Charging VRLA Batteries in Cycling Applications," Annu. Battery Conf. Appl. Adv., 14th IEEE, pp. 155-59, 1999.

2. E. D. Sexton and J. B. Olson, "Characterization of Plates from a Spiral Wound HEV Battery," Annu. Battery Conf. Appl. Adv., 14th IEEE, pp. 25-29, 1999.

3. T. T. Sack, J. C. Tice, and J. Reynolds, "Segmented Battery Charger for High Energy 28V Lithium Ion Battery," Annu. Battery Conf. Appl. Adv., 16th IEEE, pp. 157-59, 2001.

4. D. Berndt and U. Teutsch, "Float Charging of Valve-regulated Lead-acid Batteries : A Balancing Act between Secondary Reactions," J. Electrochem. Soc., 143 [3] 790-98 (1996).

5. S. Atlung and B. Zachau-Christiansen, "Failure Mode of the Negative Plate in Recombinant Lead/acid Batteries," $J$. Power Sources., 52 [2] 201-09 (1994).

6. P. T. Krein, S. West, and C. Papenfuss, "Equalization Requirements for Series VRLA Batteries," Annu. Battery Conf. Appl. Adv., 16th IEEE, pp. 125-30, 2001.

7. A. V. Virkar, "A Model for Solid Oxide Fuel Cell (SOFC) Stack Degradation," J. Power Sources., 172 [2] 713-24 (2007).

8. H.-T. Lim and A. V. Virkar, "A Study of Solid Oxide Fuel Cell Stack Failure by Inducing Abnormal Behavior in a Single Cell Test," J. Power Sources., 185 [2] 790-800 (2008).

9. H.-T. Lim and A. V. Virkar, "Electrochemical Degradation of Fuel Cell : Effect of Electrolyte Composition," ECS Trans., 25 [2] 447-56 (2009).

10. H.-T. Lim, S. C. Hwang, M. G. Jung, H. W. Park, M. Y. Park, S.-S. Lee, and Y.-G. Jung, "Degradation Mechanism of Anode-supported Solid Oxide Fuel Cell In Planar-cell Channel-type Setup," Fuel Cells., 13 [5] 712-19 (2013).

11. M. Y. Park, Y. G. Jung, and H.-T. Lim, "Delamination-resistant Bi-layer Electrolyte for Anode-supported Solid Oxide Fuel Cells," Solid State Ionics., 262 438-43 (2014). 